\title{
UK's Dounreay reprocessing plant to shut
}

[LONDON] The British government has announced that its nuclear-waste reprocessing plant at Dounreay, Scotland, once the heart of the UK fast-reactor programme, is to close within the decade. The plant will cease to take further reprocessing orders with immediate effect.

A commitment to existing contracts including reprocessing a consignment of highly enriched uranium from Georgia (see Nature 392, 850; 1998) — will keep Dounreay open until 2006. After then, the government wants to turn the site into a model for decommissioning nuclear plants.

However, it is anticipated that redundancies are unlikely to be large-scale. Most of the site's 1,600 staff are expected to become involved in the decommissioning, which will last well into the next century.

The decision to close the plant has been met with disappointment - though not surprise - by Britain's nuclear industry. Dounreay has rarely been out of the headlines in recent years because of its controversial safety record.

Environmental campaigners such as the Friends of the Earth group, on the other hand, are delighted with the decision, but want an immediate end to reprocessing at Dounreay, which is the smaller of Britain's reprocessing facilities, and deals only with fuel from experimental reactors.

The campaigners are also calling on the government to shut down the Thermal Oxide Reprocessing Plant (THORP), at Sellafield in the northwest of England, which handles the bulk of waste from nuclear

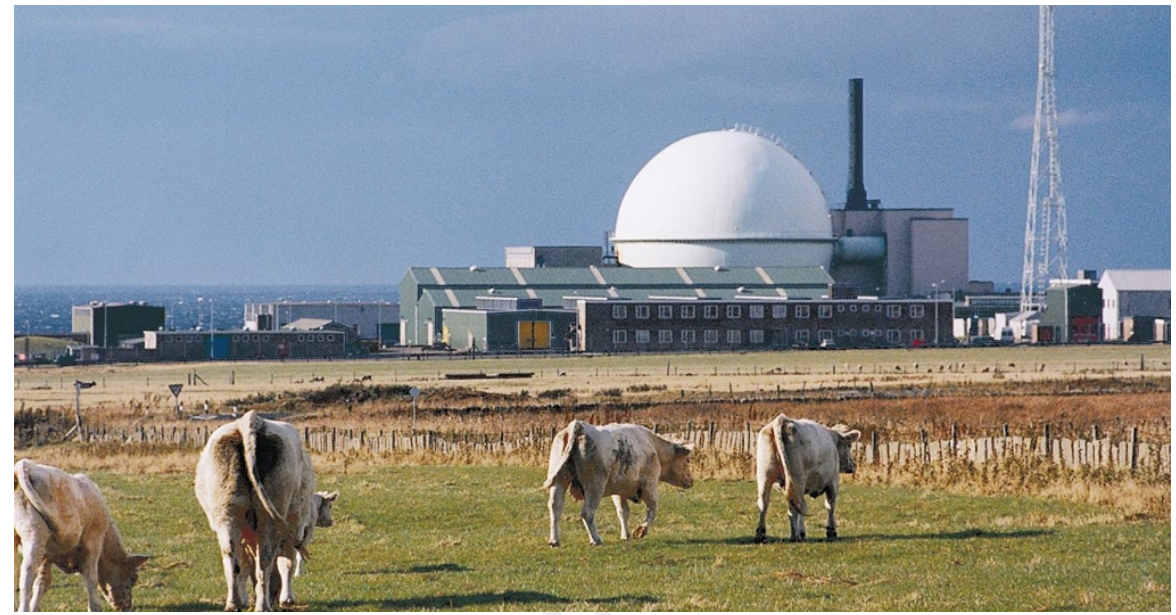

Safely grazing? Dounreay's controversial safety record has kept it in the headlines in recent years.

power plants in the United Kingdom and overseas.

The Sellafield plant, however, will probably remain unaffected by the Dounreay decision. THORP remains at the centre of plans for Britain to attract the world's reprocessing business, particularly in the event of a revival in nuclear power as a source of energy that does not contribute to global warming.

Dounreay is being closed because there is no "economic case" for supporting commercial reprocessing, according to the United Kingdom Atomic Energy Authority, which advised the government to close the site.

However, sources in the UK Department of the Environment say that the site's controversial management and safety record, and the ensuing negative publicity, were also factors in the decision.

The government had been considering Dounreay's future for a number of months. The site is badly contaminated. And it is currently closed while officials from the Environment Agency and the Nuclear Installations Inspectorate carry out an audit of safety procedures following concerns over the security of plutonium at the plant, and the accidental cutting of an electric power cable.

Dounreay is the most complex of Britain's civilian nuclear sites. Commercial reprocessing of waste was just one of its various activities. The site was initially built in 1956 as a pilot plant for Britain's nowdefunct fast-breeder reactor programme, which was cancelled in 1988 . Ehsan Masood

\section{Germany owns up to weapons-grade uranium deal with Russians}

[MUNICH] The German federal government, after years of evasion about the likely source of weapons-grade highly enriched uranium (HEU) fuel required by a controversial new research reactor, has admitted negotiating a bilateral agreement with the Russian government for the delivery of such fuel.

According to the deal, which has yet to be approved by the Russian parliament, the Russian company Techsnabexport will provide the German company Nukern with up to $1,200 \mathrm{~kg}$ HEU specifically for use in the FRM-II reactor being built by the Technical University of Munich.

Together with a supply of $400 \mathrm{~kg} \mathrm{HEU}$ already guaranteed from European sources, this represents sufficient fuel for the FRMII's expected 40-year lifespan.

The United States has protested to the Russian government that the deal could encourage a further increase in commerce in HEU, something it has been attempting to limit through amendments to the 1969 Non-
Proliferation Treaty, for example the Reduced Enrichment for Research and Test Reactors (RERTR) agreement of 1978.

According to the RERTR agreement, the United States - the West's only supplier of HEU until the collapse of the Soviet Union - delivers HEU only to those research reactors prepared to convert eventually to low-enriched uranium (LEU), or those technically unable to do so.

The FRM-II is the only one of 12 large research reactors built since 1978 that has been designed to burn HEU. The United States has already bought up large quantities of Russian HEU stockpiles to prevent it from coming on to the general market.

The US Department of Energy claims that the FRM-II could easily convert to LEU and still deliver the same neutron flux. But the Technical University has aggressively resisted local and international pressure to redesign the reactor, arguing that this would require the university to submit to new time- consuming licensing procedures.

Gert von Hassel, a spokesman for the FRM-II programme, maintains that the research reactor could still receive HEU fuel from the United States through a US-Euratom agreement signed two years ago which allows delivery of HEU fuel to European reactors that meet RERTR criteria.

But the US energy department has made clear that the FRM-II will not receive US HEU fuel even if its operators were to decide in future to meet criteria by agreeing to convert, because it has refused to convert while in the design stage.

Irene Sturm, a member of the Bavarian parliament for the Green party, claims that the Technical University has "deliberately tried to obscure the facts about negotiations with Russia over delivery of HEU".

But von Hassel rejects these charges. "We have tried to explain technical matters to the general public in a simple way," he says.

Alison Abbott 